\title{
THE USE OF COLLOCATIONS BY B1, B2 AND C1 LEVEL STUDENTS OF ENGLISH AS L2 AT THE UNIVERSITY OF ZENICA
}

\author{
Edina Rizvić-Eminović \\ University of Zenica, BiH \\ Kamiah Arnaut-Karović \\ University of Zenica, BiH
}

\begin{abstract}
The paper presents a research into the use of collocations by B1, B2 and C1 level students of English at the University of Zenica conducted by analysing student's examination papers. Collocations represent an important segment of the knowledge of a foreign language and its vocabulary. They appear in many different forms and learning them might be seen as the most difficult task of L2 learning. Difficulties in using collocations appear even at advanced levels of language learning. A preliminary study into the use of collocations by B2 level students of English showed that the students used proper lexical collocations in about $60 \%$ and proper grammatical collocations in about $50 \%$ of the cases. In view of those results, a research was conducted among B1, B2 and C1 level students of English at the English Department of the University of Zenica to investigate their use of collocations. Student translations were analysed with a focus on the different types of collocations. The translations were produced as a part of their final examination in the Contemporary English courses 1 through 8 corresponding to the different CEFR levels analysed. We assumed that the results of the students in all four years of the English studies would be consistent with the results of the preliminary study, and that there would be no significant difference between the use of grammatical and lexical collocations.
\end{abstract}

Key words: collocations, lexical collocations, grammatical collocations 


\section{Introduction}

Definitions of collocations are numerous. All of them imply "some kind of syntagmatic relation of words" (Nesselhauf, 2004: 11). The simplest definition would be the one by McCarthy \& O’Dell (2006)who state that "a collocation is two or more words that often go together" (p. 6). "Collocations are semantically arbitrary restrictions which do not follow logically from the propositional meaning of word" claims Baker (1992: p. 47). They represent the "co-occurrence of words at a certain distance" (Nesselhauf, 2004: 11), however, frequent co-occurrence, more frequent than randomly combined words in a language. They are "a type of word combination... that is fixed to some degree but not completely" (Nesselhauf, 2004: 12). Gelbukh et al. (2013: iii) restrict the definition of collocations to lexical relations only. Some examples are: give a lecture, make a decision, and lend support. In addition to the term collocation, they use the term 'restricted lexical co-occurrence' to describe "expressions in which one word chooses another one to convey a particular meaning in an unmotivated, unpredicted way" (Gelbukh, 2013: 4).

The definition of collocations adopted in this paper is the one proposed by Benson et al. (2010)that collocations are words that "regularly combine with certain other words or grammatical constructions" (xiii). They are recurrent and semifixed, which implies that idiomatic expressions are excluded. Collocations are divided into grammatical and lexical. Lexical collocations consist of a combination of two lexical words. Grammatical collocations consist of a dominant word, usually lexical and a preposition or a grammatical construction.

Words paired in a collocation are referred to as collocates. Collocates are "co-selected by the speaker or writer and they are not a chance co-occurrence" (Cheng, 2012: 77). The collocates of a word are words which most frequently appear several words to the left or right of that word, the number of words ranging from four to seven, depending on the author.

Citing Firth's understanding of the term collocation, Taylor (2012: 106) notes that "collocation is a matter of "mutual expectancy" (Firth 1968 [1957]: 181), of "the company [that a word] keeps" (p. 179)". Taylor (ibid) further adds that "very often, the use of a word or expression generates expectations as to the surrounding words in the discourse". According to him (Taylor, 2012), the knowledge of collocational preferences constitutes an aspect of "an idiomatic command of the language" (p. 107). The knowledge of collocations is also referred to as 'collocational competence' (Mukherjee (2009) in Cheng, 2012: 172). Second language learners have to acquire this knowledge and their intuition in this regard is usually unreliable. 
Collocations are highly important in language studies. Meaning of words cannot be established by examining them in isolations. Cheng (2012) notes that a "collocation is a good guide to meaning" (p. 8) as collocations may reveal meanings of words which are often associated with specific contexts. O'Keeffe (2010: 203) notes that collocations help us explore the different senses or uses of words, which usually appear in different phraseological patterns and structures. Additionally, O'Keeffe refers to 'semantic prosodies' or the specific meanings that collocates can take on (2010: 66) in different contexts.

Elaborate procedures have been developed within the field of corpus linguistics in pursuit of the frequency of words occurring together. Computerized or manual, small-scale, corpora are set up to that end given that a single pairing of words is usually not sufficient (Viana, 2011:23).

The principle of language economy teaches us that perfect synonyms or words that can be used interchangeably in any context hardly exist in any language. Big and large, for example are synonyms in English. However, "you prepare a big (\#large) surprise for someone and pay a large (\#big) amount of money for something" (Taylor, 2012: 108). Consequently, collocations are important for language teaching because of the principle of "more frequent = more important to learn" (Leech in Meunier et al., 2011: 12). More frequent words are thus more useful to the learner both for comprehension and for production. Collocations have a great deal of relevance to language teachers in preparing teaching materials, designing tests or explaining subtle differences in language use.

Some studies have shown that it is important to study collocational patters, even of more frequent words. Although such words are commonly considered easy or well-known, a study such as that of Nesselhauf (2004) has indicated that a group of Norwegian learners of English have not mastered them even at an advanced level. The importance of collocations for Bosnian learners of English is stressed in Riđanović's contrastive grammar of English and BCS (2007), particularly in the context of adjectives which may be attributed to nouns. One such example is the use of heavy with rain in English, and the inadequacy of its most frequent translation equivalent teška with kišain BCS (p. 11). Riđanović (2007) dedicates an entire chapter to the 'company that words keep' (pp. 352-61), which abound with examples of contrastive differences in the use of collocations in the two languages.

Studies investigating the use of English collocations among BCS learners are rare, however, almost non-existent since the field of corpus linguistics has not yet become established among linguists in the region. This paper is thus among the first 
to present the results of an analysis of the collocation comprehension and production among different learner levels.

Difficulties in using collocations appear even at advanced levels of language learning. Nevertheless, learners need to be aware of frequent collocations or exceptions. A preliminary study into the use of collocations by B2 level students of English conducted by the authors showed that the students used proper lexical collocations in about $60 \%$ and proper grammatical collocations in about $50 \%$ of the cases. In view of those results, this research was conducted among B1, B2 and C1 level students of English at the English Department of the University of Zenica to investigate their use of collocations. Student translations were analysed with a focus on the different types of collocations. The translations were produced as a part of their final examination in the Contemporary English courses 1 through 8 corresponding to the different CEFR levels analysed. We assumedthat the results for the students in all four years of the English studies would be consistent with the results of the preliminary study, and that there would be no significant difference between the use of grammatical and lexical collocations.

Given that there is insufficient research into the use of collocations by BCS learners of English as L2, and having attested constant difficulties the students encounter in producing collocations at all levels, the authors have set out to carry out a study with the aim to:

1. Quantify the use of correct or appropriate collocations, both lexical and grammatical, among the target group of English as L2 students;

2. Identify the types of collocations that present the most difficulties for students of the different levels analyzed;

3. Establish whether there is any difference in the comprehension of English collocations when translating them from English to BCS and their production when translating them from BCS to English;

4. Identify, where relevant, the contrastive differences between the two languages that might contribute to the incorrect use of some types of collocations;

5. Offer a classification of collocation mistakes that might help BCS teachers of English in teaching collocations;

6. Establish the possible intralinguistic factors that affect the use of appropriate collocations;

7. Based on the results of the above analyses, attempt to make predictions regarding the appropriate use of the different types of collocations among the BCS learners of English in general;

The secondary aim of the study is to:

1. Collect a corpus of mistakes in using collocations (the so called deviant colloca- 
tions) to be used in further investigations and contrastive analyses of the two languages.

The results of the study have implications for teaching collocations at the university level. By quantifying the data, the study offers an insight into the types of collocations which seem to be the most difficult to acquire to BCS learners of English and enables generalizations about the collocation comprehension and production of BCS learners of English as L2.

\section{Method}

The study is set up within the frameworks of Applied Linguistics as defined in Cook (2009: 1). It identifies and analyzes a specific practical problem of language, that of the comprehension and production of collocations by B1, B2 and C1 level students of English as L2.

It also touches on some principles of corpus linguistics, as it includes a collection and analysis of a learner corpus.

Collocations are generally studied by analyzing both large computerized corpora and small learner corpora. This paper is a result of collecting a small-scale corpus of learner translation of collocations comprising 169 collocations analyzed in a total of 1395 instances of use.

The learners are students of English in the first, second, third and fourth year of studies at the English Department of the University of Zenica. The corpus of student translations was analyzed with a focus on the different types of collocations. The translations were produced as a part of their final examination in the Contemporary English Language (CEL) courses 1 through 8 corresponding to the different CEFR levels analyzed and cover a range of topics. Based on the University Curriculum of the English Language and Literature studies, the students completing the CEL1, CEL2 and CEL3 courses are B1 students. The students completing the CEL4, CEL5 and CEL6 courses are B2 students, and the students completing the CEL7 and CEL8 courses are C1 students. The CEL7 examination papers have not been included in this study though, since under the CEL7 course syllabus the students are not required to produce any translations as a part of their final exam in the course.

The papers were selected randomly from the groups of papers in CEL1 through CEL8, CEL7 excluded, regardless of the student score and grade. The papers analyzed were written over a time span of eight years, from 2008 to 2015. The 
collocations were extracted manually. The study therefore relies on the production data. A total of 349 papers have been analyzed.

All types of collocations were analyzed, both grammatical and lexical, identified in the student written translations. The lexical collocations included the following 6 combinations: verb + noun; adjective + noun; noun + verb; noun $1+$ of + noun 2; adverb + adjective; verb + adverb. The grammatical collocations included the following 8 combinations and structures: noun + preposition; noun + to infinitive; noun + that clause; preposition + noun; adjective + preposition; adjective + to infinitive; adjective + that clause; verb + preposition.

Not all combinations were identified in all of the groups of papers. Average correct or appropriate use was calculated for each of the above combinations within the groups of lexical (LC) and grammatical collocations (GC). Then the average was identified for the group of LCs and the group of GCs separately to establish whether there is any difference in the use of the two. The results indicate in percentage only the average correct use, as the numbers for the incorrect use would be redundant. This procedure was applied first to quantify the correct use of LCs and GCs in the student translations from English to BCS, namely to identify the degree of their collocation comprehension. The same procedure was then applied to the translations from BCS to English to identify the degree of the student collocation production. Once all the averages were obtained for all the CELs courses individually, the average LC and GC comprehension and production were calculated for each of the CEFR levels analyzed, namely B1, B2 and C1.

\section{Results}

As shown in Table 1 below, the analysis of the student written translations as a part of their final examination paper in CEL 1 through CEL8 (CEL7 excluded) comprised a total of 169 collocations, analyzed in 1395 instances of use. The results are presented separately for the lexical and grammatical collocations. A total of 60 collocations were extracted at all of the three levels and analyzed in 634 instances of use in the student translations from English to BSC. This data refers to the collocation comprehension. The data referring to the collocation production, on the other hand, included a total of 109 collocations analyzed in 761 instances of use. Since the syllabi for CEL1, CEL2, CEL3 and CEL4 do not incorporate translation from English to BCS into the final examination, the lines provided for those courses remain empty. 
Table 1

Numbers of lexical and grammatical collocations, as well as instances of their use for each Contemporary English course

$\mathrm{E} \rightarrow \mathrm{BCS} \quad \mathrm{BCS} \rightarrow \mathrm{E}$

\begin{tabular}{cccccccc}
\hline LCs & GCs & $\begin{array}{l}\text { LC } \\
\text { Inst. }\end{array}$ & $\begin{array}{c}\text { GC } \\
\text { Inst. }\end{array}$ & LCs & GCs & $\begin{array}{l}\text { LC } \\
\text { Inst. }\end{array}$ & $\begin{array}{c}\text { GC } \\
\text { Inst. }\end{array}$ \\
\hline- & - & - & - & 6 & 5 & 69 & 54
\end{tabular}

\begin{tabular}{|c|c|c|c|c|c|c|c|c|}
\hline CEL1 & - & - & - & - & 6 & 5 & 69 & 54 \\
\hline CEL $1 \Sigma$ & - & & - & & 11 & & 123 & \\
\hline CEL2 & - & - & - & - & 9 & 4 & 104 & 27 \\
\hline CEL $2 \Sigma$ & - & & - & & 13 & & 131 & \\
\hline CEL3 & 5 & 5 & 94 & 72 & 7 & 5 & 50 & 36 \\
\hline CEL $3 \Sigma$ & 10 & & 166 & & 12 & & & 86 \\
\hline B1 $\Sigma$ & 10 & & 166 & & 36 & & 230 & \\
\hline CEL4 & - & - & - & - & 7 & 5 & 60 & 74 \\
\hline CEL $4 \Sigma$ & - & & - & & 12 & & & 134 \\
\hline CEL 5 & 7 & 10 & 70 & 100 & 12 & 7 & 120 & 70 \\
\hline CEL $5 \Sigma$ & 17 & & 170 & & 19 & & 190 & \\
\hline CEL 6 & 12 & 5 & 120 & 50 & 14 & 5 & 74 & 28 \\
\hline 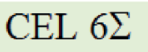 & 17 & & 170 & & 19 & & 102 & \\
\hline B2 $\Sigma$ & 34 & & 340 & & 50 & & 426 & \\
\hline CEL 8 & 12 & 4 & 96 & 32 & 14 & 9 & 60 & 45 \\
\hline CEL $8 \Sigma$ & 16 & & 128 & & 23 & & 105 & \\
\hline $\mathrm{C} 1 \Sigma$ & 16 & & 128 & & 23 & & 105 & \\
\hline
\end{tabular}

Note. $E=$ English $; B C S=$ Bosnian/Croatian/Serbian; $L C s=$ Lexical Collocations; GCs = Grammatical Collocations; Inst. = Instances; CEL = Contemporary English Language; CEFR = Common European Framework of Reference for Languages; B1, B2, C1 refer to CEFR levels; $\Sigma=$ the total number of collocations or instances. 
Table 2 below was produced by analyzing the percentages of correct collocation use for each of the six types of LCs and eight types of GCs referred to in the Method section andidentified in the texts assigned for translation. Not all of the types of collocations were identified, however, in all the different CEL translation assignments. As in Table 1, the empty lines are due to the lack of translation assignments from English to BCS in some CEL courses.

\section{Table 2}

Percentage of correct collocation comprehension and production per Contemporary English courses and the corresponding CEFR levels

\begin{tabular}{|c|c|c|c|c|c|c|}
\hline \multirow{3}{*}{$\begin{array}{l}\text { CEFR } \\
\text { level }\end{array}$} & \multirow{3}{*}{$\begin{array}{l}\text { Course \& } \\
\text { course } \chi\end{array}$} & \multirow{2}{*}{\multicolumn{2}{|c|}{$\begin{array}{l}\text { Comprehension } \\
(\%)\end{array}$}} & \multirow{2}{*}{\multicolumn{2}{|c|}{ Production (\%) }} & \multirow{3}{*}{$\begin{array}{l}\chi \\
\text { for CEFR } \\
\text { level }\end{array}$} \\
\hline & & & & & & \\
\hline & & LCs & GCs & LCs & GCs & \\
\hline \multirow{6}{*}{ B1 } & CEL 1 & - & - & 46.37 & 59.01 & \multirow{6}{*}{$36.32 \%$} \\
\hline & CEL $1 \chi$ & - & & 52.69 & & \\
\hline & CEL2 & - & - & 48.04 & 22.22 & \\
\hline & $\operatorname{CEL} 2 \chi$ & - & & 35.13 & & \\
\hline & CEL3 & 29.78 & 59.72 & 6.0 & 19.44 & \\
\hline & CEL $3 \chi$ & \multicolumn{2}{|l|}{44.72} & \multicolumn{2}{|l|}{12.72} & \\
\hline \multirow{6}{*}{ B2 } & CEL4 & - & - & 48.33 & 62.16 & \multirow{6}{*}{$48.28 \%$} \\
\hline & $\operatorname{CEL} 4 \chi$ & - & & 55.25 & & \\
\hline & CEL 5 & 65 & 59.8 & 29.4 & 30.5 & \\
\hline & CEL $5 \chi$ & 62.4 & & 27.45 & & \\
\hline & CEL 6 & 58.3 & 75 & 26.8 & 32.5 & \\
\hline & CEL $6 \chi$ & \multicolumn{2}{|l|}{66.65} & \multicolumn{2}{|l|}{29.65} & \\
\hline \multirow[b]{2}{*}{ C1 } & CEL 8 & 67.5 & 87.5 & 69.45 & 71.68 & \multirow[b]{2}{*}{$74.03 \%$} \\
\hline & CEL $8 \chi$ & 77.5 & & 70.56 & & \\
\hline
\end{tabular}

Note. LCs = Lexical Collocations; GCs = Grammatical Collocations;CEL = Contemporary English Language; CEFR = Common European Framework of Reference for Languages; B1, B2, C1 refer to CEFR levels; $\chi=$ the average. Figures 1 through 4 below present the data extracted from Table 2. Figure $1 \mathrm{com}$ 
Figures 1 through 4 below present the data extracted from Table 2. Figure $1 \mathrm{com}$ pares the correct use of GCs and LCs in the student translations from English to BCS, measuring their comprehension at B1, B2 and C1 level. It indicates that the students' comprehension of GCs is better than their comprehension of LCs by about $50 \%$ at B1 level, by only $6 \%$ at B2 level and by $20 \%$ at C1 level.

Figure 1

Comparison of comprehension of LCs and GCs for different CEL courses

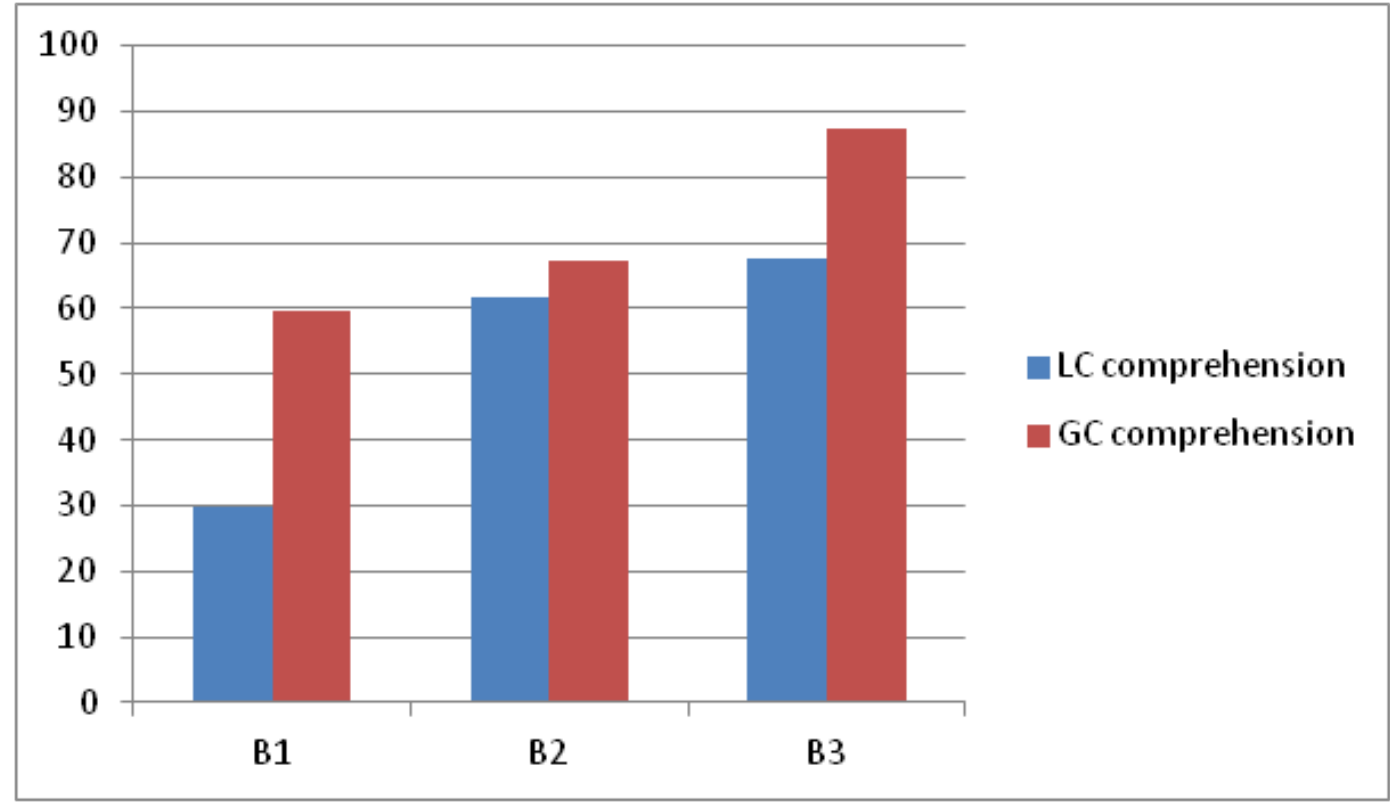

Note. LCs = Lexical Collocations; GCs = Grammatical Collocations; CEL = Contemporary English Language.

As opposed to the previous figure, Figure 2 compares the correct use of GCs and LCs in the student translations from BCS to English, measuring their production. It indicates that the average students' production of GCs too is better than their production of LCs. The difference in the case of production, though, is less significant than in the case of comprehension and ranges from about only $0.1 \%$ at B1 level, through $7 \%$ at $\mathrm{B} 2$ level to $2 \%$ at $\mathrm{C} 1$ level. 
Figure 2

Comparison of production of LCs and GCs for different CELs

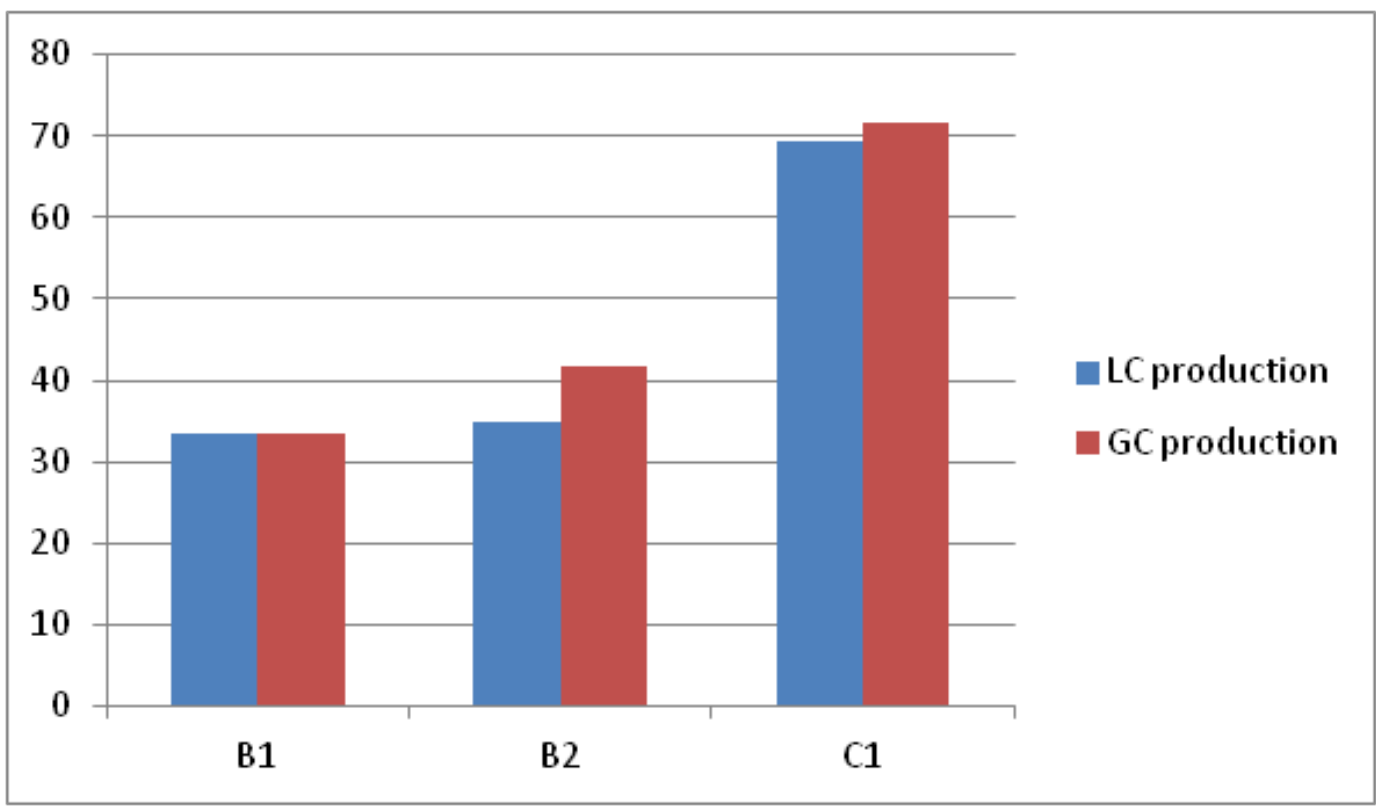

Note. $L C s=$ Lexical Collocations; $G C s=$ Grammatical Collocations; CEL = Contemporary English Language.

Figure 3 compares the average percentage of comprehension and production of both LCs and GCs at the different levels analyzed. It shows that, at B2 and $\mathrm{C} 1$ levels students are more successful in comprehending than in producing collocations by about $12 \%$ and $7 \%$ respectively. They are almost equally successful in comprehending and producing collocations at B1 level, the difference being a mere $0.5 \%$ in favor of the production.

\section{Figure 3}

Comparison of comprehension and production for different CEFR levels

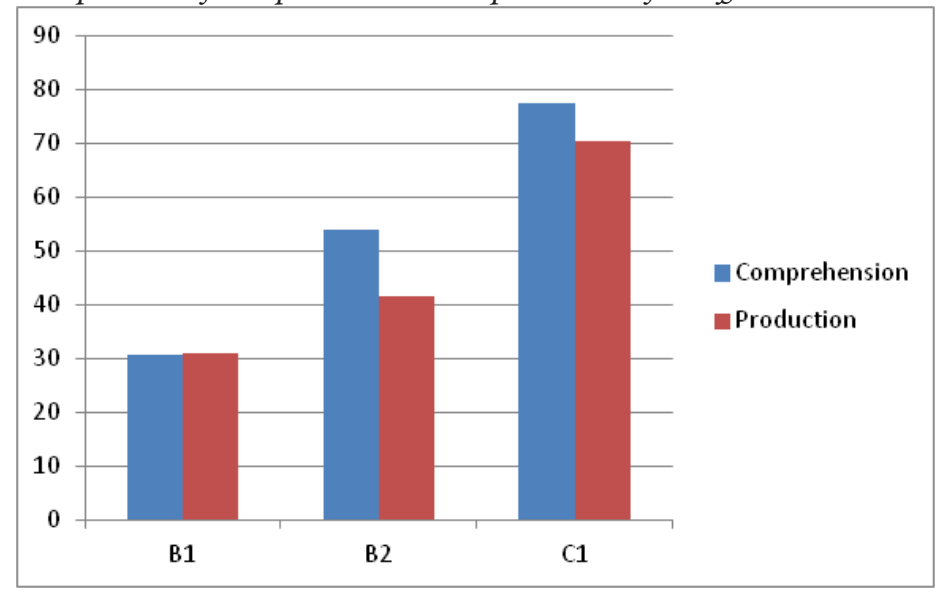


Note. CEFR = Common European Framework of Reference for Languages; B1, B2, C1 refer to the CEFR levels analyzed in the study.

Figure 4 compares the students' overall competence in LCs and GCs at the different levels when using them both when translating from English to BCS and vice versa. It indicates that, in general, students are more competent in using GCs at all levels than in using LCs, the difference ranging from about $22 \%$ at B1 level, through $6 \%$ at $\mathrm{B} 2$ level to $11 \%$ at $\mathrm{C} 1$ level. These results are contrary to the results of the preliminary study.

Figure 4

The percentage of correct use of LCs and GCs at B1, B2, and C1 levels

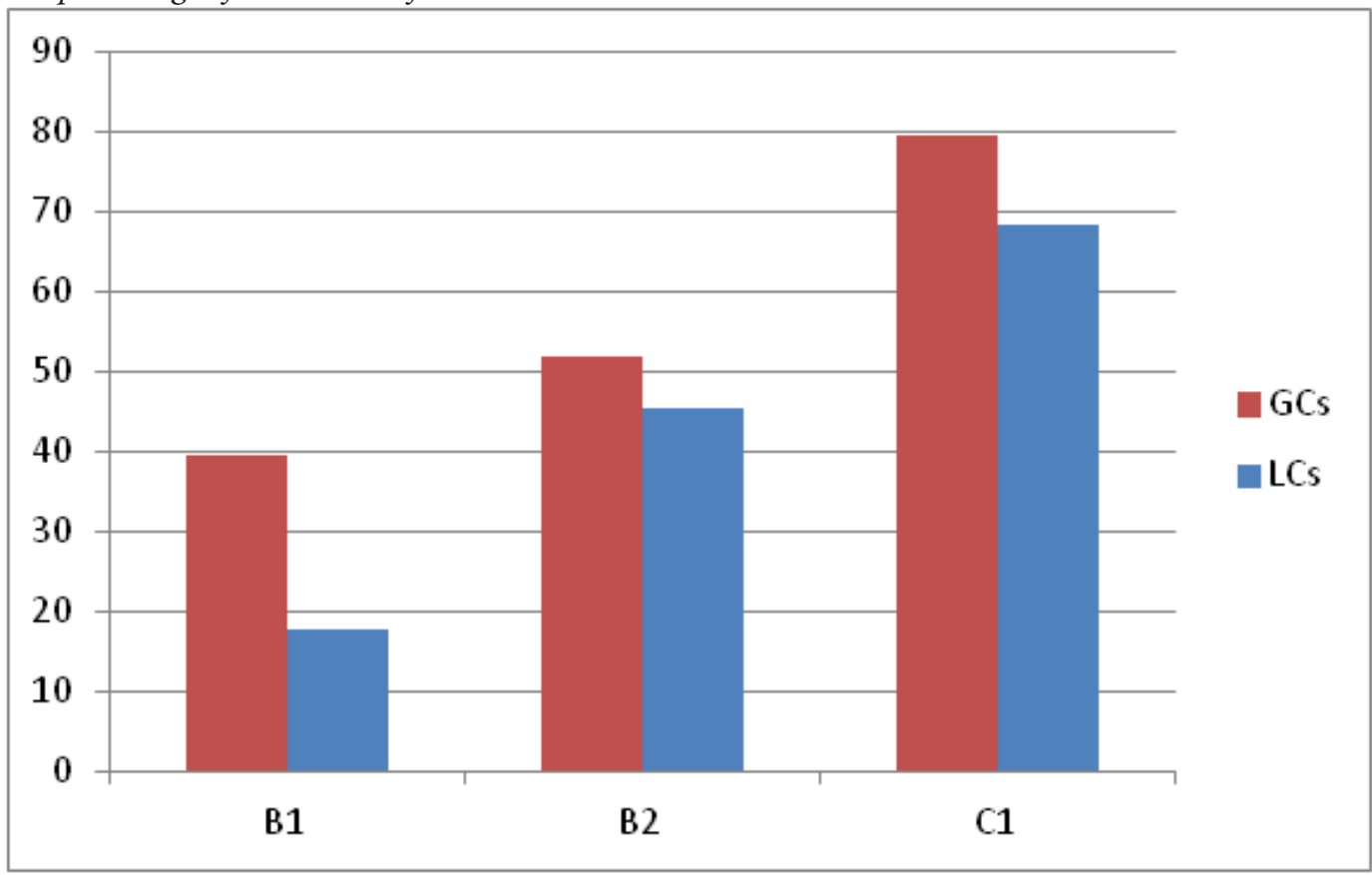

Discussion

In view of the aims set in the study as well as the results obtained in the course of the analyses, numerous observations can be made and conclusions drawn referring to the aims of the study.

As shown in Figure 4 above, the students display greater competence in both the comprehension and the production of GCs at all the three levels analyzed. What is significant is that these results are not consistent with the results of the preliminary study, where B2 level learners showed a better mastery of lexical collocations by about $10 \%$. A conclusion may be drawn that, when analyzing collocations, it 
is important to include more collocations as well as instances of their use and to set up a larger scale corpus when making generalizations about student collocation competence. One of the drawbacks of the study, however, may be that it lacks elicitation tests for students. Such tests would serve as a control test for this study and the correspondence of the results of such tests would make this study more reliable. The students' greater competence in the comprehension of GCs at all the three levels may be ascribed to the fact that GCs contain combinations such as noun + to infinitive or noun + that clause, which are commonly translated with clausal constructions into BCS and hardly contain an alternative translation. Their efforts to lift hundreds of millions of people out of poverty... is translated as ... Njihovi napori da izbave stotine miliona ljudi od siromaštva... Or assumptions... that China only supports dictatorship is translated as pretpostavke... da Kina samopodržava diktatorstvo. The same is the case for the production of GCs as in snaga da istraju, the only translation of which is with clausal construction the strength to endure. Lexical collocations, on the other hand, consist of different combinations of lexical words. Poor vocabulary has been identified as the reason for lower success rate in the comprehension and production of lexical collocations. This conclusion also applies to the third aim set in the study.

Based on the results of the correct translation of both LCs and GCs, the following ranking list of the top three combinations for the comprehension of LCs may be made:

1. adverb + adjective, as in equally important (BCS: jednakovažan);

2. verb + noun, as in its aid brings no benefit to ordinary people (BCS: njena pomoć nedonosi nikakvu korist ljudima);

3. adjective + noun, as in free flow of information (BCS: slobodan protok informacija).

In terms of the comprehension of GCs, the combinations are ranked as follows:

1. verb + preposition, as in stared at him (BCS: zurio u njega),

2. adjective + that clause, as in I was aware that Black would... (BCS: Bila sam sigurna da će Black...);

3. noun + that clause, as in assumptions... that China only supports dictatorship.

In terms of the production of LCs, where the success rates are generally much lower than in the case of GCs and do not exceed $40 \%$, the list is as follows:

1. adjective + noun, as in široki konsenzus (E: broad/wide consensus);

2. verb + noun, as in udahnuti život (E: breathe life into);

3. verb + adverb, as in silom ukloniti (E: remove forcibly).

The ranking list for the production of GCs is as follows: 
1. noun + that clause, as in nada da će moj budući svijet biti oblikovan... (E: the hope that my future world would be shapes);

2. noun + to infinitive, as in snaga da izdržim (E: strength to endure);

3. adjective + that clause, as in oduševljena što može doći (E: delighted that she could come).

The most difficult for production seem to be the constructions containing a preposition, as in the verb + preposition combination (e.g. učestvovati u događaju, translated incorrectly as participate ${ }^{*}$ at an event) or the preposition + noun combination (e.g. u to vrijeme, translated incorrectly as ${ }^{*}$ in that time).

These ranking lists may be applied to all the target levels. However, the success rates are not identical at all three of them. In view of the extensiveness of the study, the authors believe that the above ranking lists apply to the collocation competence at B1, B2 and C1 level BCS learners of English in general, which is a conclusion that refers to the sixth aim of the study.

The following paragraphs contain the conclusions drawn in respect to the final four aims of the study, based on the analysis of the mistakes the students made in the comprehension and the production of collocations.

The reasons for the mistakes are varied. For example, a single translation equivalent in BCS covers two or three expressions in English that may or may not be synonyms or near-synonyms. Synonymous expressions in English usually have certain shades of meanings, for which reason some synonymous expressions are not always mutually interchangeable in all the contexts. The usual mistakes found in the corpus are related to the following:

- Poor comprehension of these shades of meaning;

- A single translation equivalent in BCS that can cover different contexts with the same expression in L1.

One example is the English pick up/lift/raise/elevate and BCSpodići. In BCS the single expression podići may be used in different contexts. However, in English, the three above-stated verbs are not always mutually interchangeable. Therefore, the following phrase was translated in some cases with an incorrect near-synonym: podići kofer? raise/?carry a suitcase. These collocations are marked as semantically questionable not because they are not possible in English but because they might be acceptable and fit into different contexts other than those found in the corpus. 
Another example is the phrase: transform the impulses into sound. The synonyms change and convert are found in the corpus. However, these two cover much broader contexts in English, whereas the expression transform is more appropriate for the texts referring to physics and physical phenomena. In some cases, however, the synonymous pairs were mutually interchangeable and completely acceptable, such as in lažna brada and false/fake beard.

Another reason for the student mistakes was their poor command of vocabulary. The students employed the following strategies in translation:

- Complete omission of the expression;

- Replacing the word with a similar word not a synonym or near-synonym but an expression with much a broader meaning (sometimes a hyperonym)

The examples for this claim are phrases such as gole pesnice (E: bare fists) translated as bare ?hands; veličanstveni predjeli (E: magnificent landscapes), translated as magnificent? areas/country/fields; or sredstvo komunikacije (E: means of communication) translated as ?instrument/device/tool/type of communication.

- Literal translation

For the petrified and fixed expressions the learners offered literal translations, as in netaknute prašume (E: virgin rainforests), which was translated as ?untouched/ intact rainforests.

- Paraphrasing or descriptive translation

Compounding is a very productive morphological operation in English which is not the case in BCS. BCS makes much more use of phrases. An example is the phrase hrana bogata vlaknima (E: fiber-rich food), which was translated in the majority of cases asfood rich with fibers or višenamjenski kućanski aparat (E: multi-purpose appliance), translated as an appliance for multiple purposes.

As indicated above, the results for GCs are generally better. Nevertheless, a certain percentage of mistakes mostly refers to usage of prepositions and prepositional phrases. One significant difference between the two linguistic systems refers to the realization of transitive verbs whose direct objects are realized by PPs not NPs. BCS and English show a number of differences in the case of some very frequently used transitive verbs. While some transitive verbs in English take PPs, such as: laugh [AT smb.]/wait [FOR smb.], in BCS the same verbs take NPs: smijati se [kome]/čekati [koga]. Therefore, frequent mistakes in the corpus in reference to GCs were the following:

- The omission of the required preposition in English which can be ascribed to literal syntactic transfer from BCS.

On the other hand, there are some BCS transitive verbs that take PP objects whereas their English equivalents take NPs. For example the English equivalents of BCS odgovoriti NA/sastati se SA/pasti NA have a different syntactic realization and re- 
quire an NP answer [NP]/meet [NP]/fail [NP]. In such cases, the learners' translation most frequently involved:

- insertion of the preposition into the English translation, as in ${ }^{*}$ answer $\mathrm{ON}$ the question $/{ }^{*}$ meet with friends $/{ }^{*}$ fail ON/AT the exam

Some verbs in BCS are intransitive but usually followed by PP adverbial. Their English equivalent is a typical transitive verb requiring an NP object. In such cases, the English transitive verb was usually converted into intransitive (following the BCS pattern) and the preposition was inserted, as in zakasniti NA voz (E: miss the train), translated as ${ }^{*}$ miss $\mathrm{ON}$ the train.

The reasons for the above strategies may be ascribed to the following factors:

- Poor vocabulary;

- Poor comprehension of the shades of meanings of synonyms or near-synonyms;

- Poor production caused by literal transfer of collocations from L1.

The most common mistakes identified in the corpus will serve as a basis for future elicitation tests in this field. Finally, the fact that the student overall collocation competence increases with the increase in the student level indicates that a more extensive and longer exposure to language as well as a better command of the language in general contributes to a better command of collocations. 


\section{E. R. Eminović, K. A. Karović}

\section{References}

Nesselhauf, Nadja(2004). Collocations in a Learner Corpus. Amsterdam/Philadelphia: John Ben jamins Publishing Company.

Taylor, John, R. (2012). The Mental Corpus, How Language is Represented in the Mind. Oxford: Oxford University Press.

Meunier, Fanny et al. (2011). A Taste for Corpora. Amsterdam/Philadelphia: John Benjamins Pub lishing Company.

Cheng, Winnie (2012). Exploring Corpus Linguistics, Language in Action.London: Routledge

O'Keeffe, Anne and McCarthy, Michael, eds. (2010).The Routledge Handbook of Corpus Linguistics. London: Routledge.

Riđanović, M. (2007).Praktičnaengleskagramatika. Sarajevo: Šahinpašić.

Viana, Vander et al. eds. (2011).Perspectives on Corpus Linguistics. Amsterdam: John Benjamins Publishing Company.

Gelbukh, Alexander and Kolesnikova, Olga (2013).Semantic Analysis of Verbal Collocations with Lexical Functions. Berlin: Springer.

McCarthy, Michael and O’Dell, Felicity (2005).English Collocations in Use. UK: Cambridge University Press.

Baker, Mona (1992). In Other Words.London: Routledge.

Benson, Morton et al. (2010) The BBI Combinatory Dictionary of English: Your Guide to Colloca tions and Grammar. Amsterdam/Philadelphia: John Benjamins Publishing Company.

Cook, Vivian, and Wei Li, eds. (2009). Contemporary Applied Linguistics, Language Teaching and Learning, V1, London: Continuum International Publishing Group 